\title{
Application of Bio-Solids as Soil Amendment in Arid Rangeland of Jordan
}

\author{
Saad M. AlAyyash ${ }^{1 *}$, Odah M. Al-Meshan², Rania S. Shatnawi ${ }^{3}$ \\ ${ }^{1}$ Civil Engineering Department, Al al-Bayt University, Mafraq, Jordan \\ ${ }^{2}$ Freelance, Amman, Jordan \\ ${ }^{3}$ Civil Engineering Department, Applied Science University, Amman, Jordan \\ Email: *saad.a@aabu.edu.jo
}

How to cite this paper: AlAyyash, S.M., Al-Meshan, O.M. and Shatnawi, R.S. (2017) Application of Bio-Solids as Soil Amendment in Arid Rangeland of Jordan. Journal of Environmental Protection, 8, 344-357. https://doi.org/10.4236/jep.2017.83026

Received: January 31, 2017

Accepted: March 28, 2017

Published: March 31, 2017

Copyright (c) 2017 by authors and Scientific Research Publishing Inc. This work is licensed under the Creative Commons Attribution International License (CC BY 4.0).

http://creativecommons.org/licenses/by/4.0/

(c) (i) Open Access

\begin{abstract}
Due to long drought periods and over utilizing of range lands in the arid lands of Jordan, the land is degraded and lost most of its natural vegetation. To rehabilitate the natural vegetation cover, there is a need to enhance the fertility of soil to be able to support vegetation under limited amounts of rainfall. One of the available and viable options that might be able to provide a solution for the soil poverty is applying materials with high organic contents such as biosolid. Bio-solids are nutrient-rich organic materials from the treatment of domestic sewage in a wastewater treatment facility. Bio-solids are a beneficial resource, containing essential plant nutrients and organic matter and are recycled as a fertilizer and soil amendment. A pilot study is designed based on randomized block design in which five treatments are used to represent the loading rates of bio-solids application. These loads were 10, 20, 30, 40 and 50 tons/ha with four replicates for the control and each application load. Samples from Bio-solid, soil and plants are tested for chemicals and microbes. Chemical tests include: $\mathrm{As}, \mathrm{Cd}, \mathrm{Cr}, \mathrm{Co}, \mathrm{Cu}, \mathrm{Hg}, \mathrm{Mo}, \mathrm{Ni}, \mathrm{Pb}, \mathrm{Se}$, and $\mathrm{Zn}$, while microbial tests include: total fecal Coliform, Salmonella, and Helminthes eggs. Results of total microbial count in bio-solids, soil and plant samples indicated that there were no detectable counts found in all of the experimental plots. Results showed increase in most of the heavy metals concentration in soil treated with bio-solids from that of soil in control plots; some of these elements doubled after applying the bio-solid. For the dry plant matter, analysis for heavy metals showed that most of the heavy metals studied were below the detection limit. Only the $\mathrm{Cr}, \mathrm{Cu}$ and $\mathrm{Zn}$ are changed but not significantly compared with the control plot. Results obtained were showed that the highest dry biomass value was obtained with bio-solids loading rate 40 tons/ha and more. Increasing rate of application after 40 tons/ha did not show significant differences in the biomass yield. Also, the total nitrogen in the plants increased by $40 \%$ for all bio-solid application loads compared with the control lot.
\end{abstract}




\section{Keywords}

Bio-Solid, Arid Lands, Soil Amendment, Rangelands, Jordan

\section{Introduction}

More than $85 \%$ of the total area of Jordan is classified as arid to semi-arid region. This area is defined based on rainfall rate as areas that suffer from desertification due to low annual rate of rainfall with an average $100 \mathrm{~mm} /$ year [1]. This large area of Jordan is considered as range lands and used for animal grazing during the spring times which extend between February and May. The wild range plants grow when enough amounts of rain fall due to limited soil moisture and lack of plant nutrients.

Due to long drought periods and over utilizing of range lands in the arid lands of Jordan, the land is degraded and lost most of its natural vegetation [2]. To rehabilitate the natural vegetation cover, there is a need to enhance the fertility of soil to be able to support vegetation under limited amounts of rainfall. Drought has severe impacts on soil quality in the arid lands and subsequently on land productivity, both with respect to its causation and its control in terms of soil immature, erosion, loss of organic matter, removal of nutrients, acidity, and destruction of soil structure. These reasons prompted the need to improve soil fertility and increase organic matters available for plants. This directed the research community to look for methods and techniques to improve the degradable dry areas using national resources.

One of the available and viable options that might be able to provide a solution for the soil poverty is applying materials with high organic contents such as bio-solid. Bio-solids are nutrient-rich organic materials from the treatment of domestic sewage in a wastewater treatment facility. Bio-solids are a beneficial resource, containing essential plant nutrients and organic matter and are recycled as a fertilizer and soil amendment.

Many studies have examined the effects of the application of bio-solids in the form of the dewatered or liquid on soil properties, plant productivity, and health hazards in arid and semiarid ecosystems. The applications of bio-solid as soil amendment need to be environmentally safe and economically viable [3]. Many studies on bio-solid applications can improve the soil physical, chemical, and biological properties, and consequently speed plant growth and increased plant biomass [4] [5] [6] [7]. The loading rate of bio-solid is the key of the degree of enhancement. Reference [8] demonstrated that land application of liquid bio-solids did not pose a significant health hazard to nearby communities. A study by Reference [6] showed that surface application of bio-solids to semiarid grassland at application rates up to 90 tons per hectare (tons/ha) has significant increase in plant production without hazardous elements to soil and plant tissues at optimum rate of 45 tons/ha. Reference [9] in a plot study showed that soils received application of 21 or 30 tons/ha of bio-solid had Carbone (C) and 
Nitrogen (N) mineralization activities and plant biomass. Reference [10] studied the application of bio-solid on soil at a loading rate up to 67 tons/ha, they found that the bio-solid application increased organic carbon up to $92 \%$ and total nitrogen up to $157 \%$. Reference [11] applied bio-solid at a rate up to 75 tons/ha and found that the optimum load is between 25 and 50 tons/ha. Reference [12] applied bio-solid at a rate up to 50 tons/ha on farming land and found that the load of 20 tons/ha is the recommended load for sustainable production.

In the arid and semi-arid range lands, adding bio-solid has a positive effect, leading to the addition of more organic carbon from plant residues and the development of root systems in the soil, which may contribute to minimizing runoff and thereby mitigating water erosion and increase soil-water content [13]. The positive impact of bio-solid application affect soil and vegetation, it increased water infiltration and soil moisture retention [14] [15]; increased vegetation growth and cover [16] [17]; improved forage quality and help restore degraded rangelands [16]; promoted specific desired plant species [18] [19] and lowered concentrations of potentially toxic elements in plant [20].

Other studies reported limitations on the application of bio-solid to rangelands. Bio-solids can result in nutrients losses such as ammonia volatilization [21]. Other research found that soil electrical conductivity increased with bio-solids application in grasslands [6] [13]. Also increased soil nematodes content in degraded rangelands resulted from surface application of bio-solids [22].

The bio-solid contains high concentration of heavy metals that might accumulate in soil due to long time application of bio-solid and subsequently increased its concentration in plant tissues [23] [24] [25].

In this study, the application of bio-solid as soil enhancement for degraded arid land soil will be examined. The desirable effects of using bio-solid such as enhancing the plant nutrients in soil will be measured at various application loads. In the other hand, the negative impact of bio-solid on soil and plant will be monitored and documented.

\section{Material and Methods}

\subsection{Study Area}

The experiment was conducted in the Hashemite University (HU) area, north of the Amman city, $\left(32^{\circ} 06^{\prime} 39^{\prime \prime} \mathrm{N}\right.$ and $\left.36^{\circ} 11^{\prime} 38^{\prime \prime} \mathrm{E}\right)$ with elevation of the study area approximately $590 \mathrm{~m}$. The topographic survey and Google Earth image of the site is shown in Figure 1.

The selected site represents typical arid land range land and is located within the premises of the HU. These arrangements are to prevent any undesirable contact from range land users with the experiment site that might cause health effect on people or animals.

The climate is semi-arid where the annual precipitation varies between 50 and $150 \mathrm{~mm}$ with annual average around $100 \mathrm{~mm}$. The rainy season extends between December and May with most of the precipitation occurs in the months of December, January and February. The vegetation in the study area is mainly scattered 


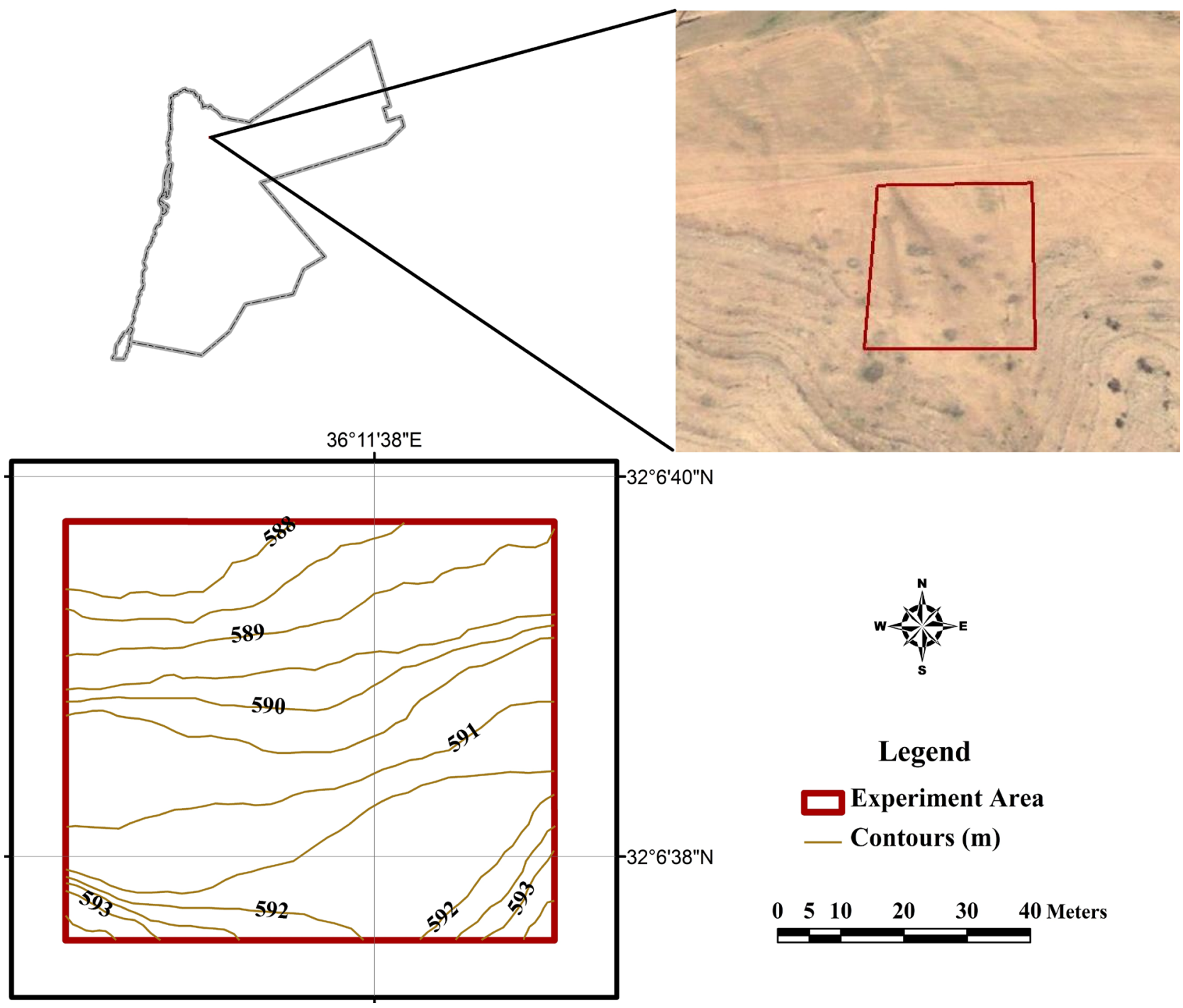

Figure 1. Location map of the study area.

shrubs and seasonal grass.

The soil in the study area was originally derived from limestone parent material. It consists of fossiliferous limestone on its upper part underline by dolomitic limestone. The soil properties for the study area are shown in Table 1.

\subsection{Experimental Setup}

The pilot study experimental design was based on randomized block design in which the five treatments were used representing the loading rates of bio-solids application. These loads were 10, 20, 30, 40 and 50 tons/ha with four replicates for the control and each application load. The control plots are indicated as 0 ton/ha application rate. The total number of plots was 24 squares with 6 meters length and 2 meters buffer zone between the plots and around the experiment site. Uniform application of bio-solids in upstream first one meter of each plot to allow its flow with the rainfall runoff to cover the rest of the plot, after first rainfall event, the bio-solid was mixed with the top soil to make sure that it is 
Table 1. Properties of soil in the study area.

\begin{tabular}{cc}
\hline Property & Characteristics \\
\hline Soil texture sand & Medium loam; Sand: $38 \%$, Clay: $16 \%$, Silt: $46 \%$ \\
Soil hydraulic conductivity & $28.38 \mathrm{~cm} \cdot \mathrm{hr}^{-1}$ \\
Water holding capacity (WHC) & $115.5 \mathrm{~mm} \cdot \mathrm{m}^{-1}$ \\
Porosity & $46.1 \%$ \\
Bulk density & $1430 \mathrm{~kg} \cdot \mathrm{m}^{-3}$ \\
pH & $7.4($ using $1: 5 \mathrm{soil}:$ water ratio) \\
Electrical conductivity (EC) & $11.6 \mathrm{mS} \cdot \mathrm{m}^{-1}$ \\
$\mathrm{CaCO}_{3}$ & $34.6 \%$ \\
\hline
\end{tabular}

covered with soil to prevent its wash away with winds. In each plot, six seedlings of Salsola species are planted, these species are the predominant wild plant for arid regions of Jordan. Figure 2 shows the schematic of the experiment where T1 is the control, T2 is 10 tons/ha application, T3 is 20 tons/ha application, T4 is 30 tons/ha application, T5 is 40 tons/ha application, T6 is 60 tons/ha application, and R1 to R4 are the replicates for each application load.

\section{Results and Discussion}

\subsection{Bio-Solid, Soil and Plant Sampling}

Samples from Bio-solid, soil and plants are tested for chemicals and microbes. Chemical tests include: $\mathrm{As}, \mathrm{Cd}, \mathrm{Cr}, \mathrm{Co}, \mathrm{Cu}, \mathrm{Hg}, \mathrm{Mo}, \mathrm{Ni}, \mathrm{Pb}, \mathrm{Se}$, and $\mathrm{Zn}$. while microbial tests include: Total Fecal Coliform, Salmonella, and Helminthes eggs.

Composite soil samples were taken from each plot at depths of 7.5 and $15 \mathrm{~cm}$ before treatments and after treatment and rainy season. The samples used for chemical and physical analysis are air dried, while soil samples used for microbiological analysis are collected in isolated protective cases to prevent exposure to elevated temperature and transferred to the laboratory as soon as possible to avoid changes in microbial population and activities and they stored at $2^{\circ} \mathrm{C}$ to $4^{\circ} \mathrm{C}$ refrigerator before analysis. The average for the replicates of each application load is reported.

The vegetation samples from each experiment plot were collected after the biosolid application and rainy season to obtain the biomass production. Plant tissues were tested for total heavy metals concentration, Nitrogen, and microbial pollution. The averages for the replicates of each application load are reported.

\subsection{Microbiological Tests}

Results of Total Fecal Coliform (TFC), Salmonella spp., and Helminthes eggs in bio-solids, soil and plant samples indicated that there were no detectable count was found in all of the experimental plots (Table 2).

\subsection{Heavy Metals}

Heavy metals concentrations were evaluated for the applied bio-solids, the soil 


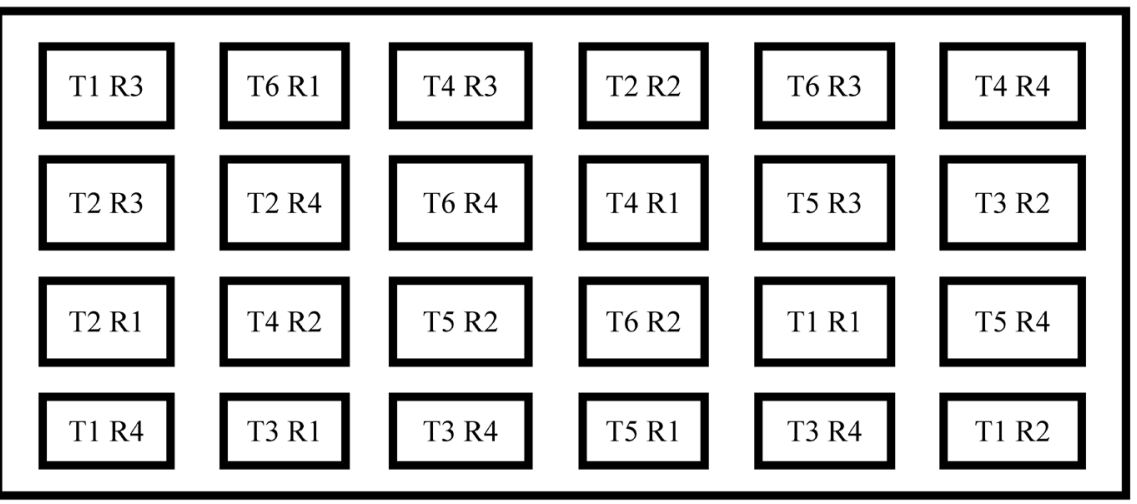

Figure 2. Schematic of land application experimental site.

Table 2. Microbial counts in bio-solids, soil and plant samples.

\begin{tabular}{ccccc}
\hline & & \multicolumn{3}{c}{ Microbial count } \\
\cline { 3 - 5 } Sample & Treatment & $\begin{array}{c}\text { TFC } \\
(\mathrm{MPN} / \mathrm{g})\end{array}$ & $\begin{array}{c}\text { Salmonella spp. } \\
(\mathrm{MPN} / \mathrm{g})\end{array}$ & $\begin{array}{c}\text { Helminthes eggs } \\
\text { (Viable cell/4g) }\end{array}$ \\
\hline Bio-solids & Mixed sample & $<0.03$ & $<0.003$ & $<0.03$ \\
Soil & All applications & $<0.03$ & $<0.003$ & $<0.03$ \\
Plant & All applications & $<0.03$ & $<0.003$ & $<0.03$ \\
\hline
\end{tabular}

after application at two depths, 7.5 and $15 \mathrm{~cm}$ and the plant tissues. The heavy metals concentrations for a composed bio-solid used in the experiment are shown in Table 3.

For soil samples, results showed increase in most of the heavy metals concentration in soil treated with bio-solids from that of soil in control plots, the $\mathrm{Hg}$ was not detected in bio-solid and soil before and after treatment while Mo did not show significant change (Figure 3). Generally these changes in heavy metals concentrations in the soil after application were related to the chemical composition of the added bio-solids that has relatively high concentration of these metals.

The results of dry plant matter analysis for heavy metals showed that most of the heavy metals studied were below the detection limit except for $(\mathrm{Cr}, \mathrm{Cu}$ and $\mathrm{Zn}$ ) were they changed but not significantly compared to the control plot (Figure 4).

\subsection{Biomass Yield}

The increased in bio-solids treatment indicated by increased plant biomass. Results obtained were showed that the highest dry biomass value was obtained with bio-solids loading rate 40 tons/ha and more. Increasing rate of application after 40 tons/ha did not show significant differences in the biomass yield (Figure 5).

\subsection{Total Nitrogen}

Results of total nitrogen in the plants indicated that an increasing in plant nitrogen content with all bio-solids application rates compared with control treatment. 
Table 3. Heavy metals concentrations in bio-solids used (Totals).

\begin{tabular}{cccccccccccc}
\hline Metal & $\mathrm{As}$ & $\mathrm{Cd}$ & $\mathrm{Cr}$ & $\mathrm{Co}$ & $\mathrm{Cu}$ & $\mathrm{Hg}$ & $\mathrm{Mo}$ & $\mathrm{Ni}$ & $\mathrm{Pb}$ & $\mathrm{Se}$ & $\mathrm{Zn}$ \\
\hline $\begin{array}{c}\text { Concentrations } \\
\left(\begin{array}{c}\text { mg/kg dry } \\
\text { weight })\end{array}\right.\end{array}$ & 46.5 & 44.7 & 1010 & 1.2 & 1200 & $\mathrm{ND}$ & 85 & 420 & 710 & 95 & 2100 \\
& & & & & & & & & & & \\
\hline
\end{tabular}

The total nitrogen percent is increased from $1.11 \%$ in the control to about $1.55 \%$ in all bio-solid applications as shown in Figure 6.

\subsection{Soil Organic Matter}

Results of soil organic matter contents after bio-solids application showed that an increase in organic matter content when soil treated with different application rates of bio-solids (Figure 7). The effect of bio-solids application on the soil organic content may be more reasonable after the adequate time for microbial decomposition of the applied bio-solids.
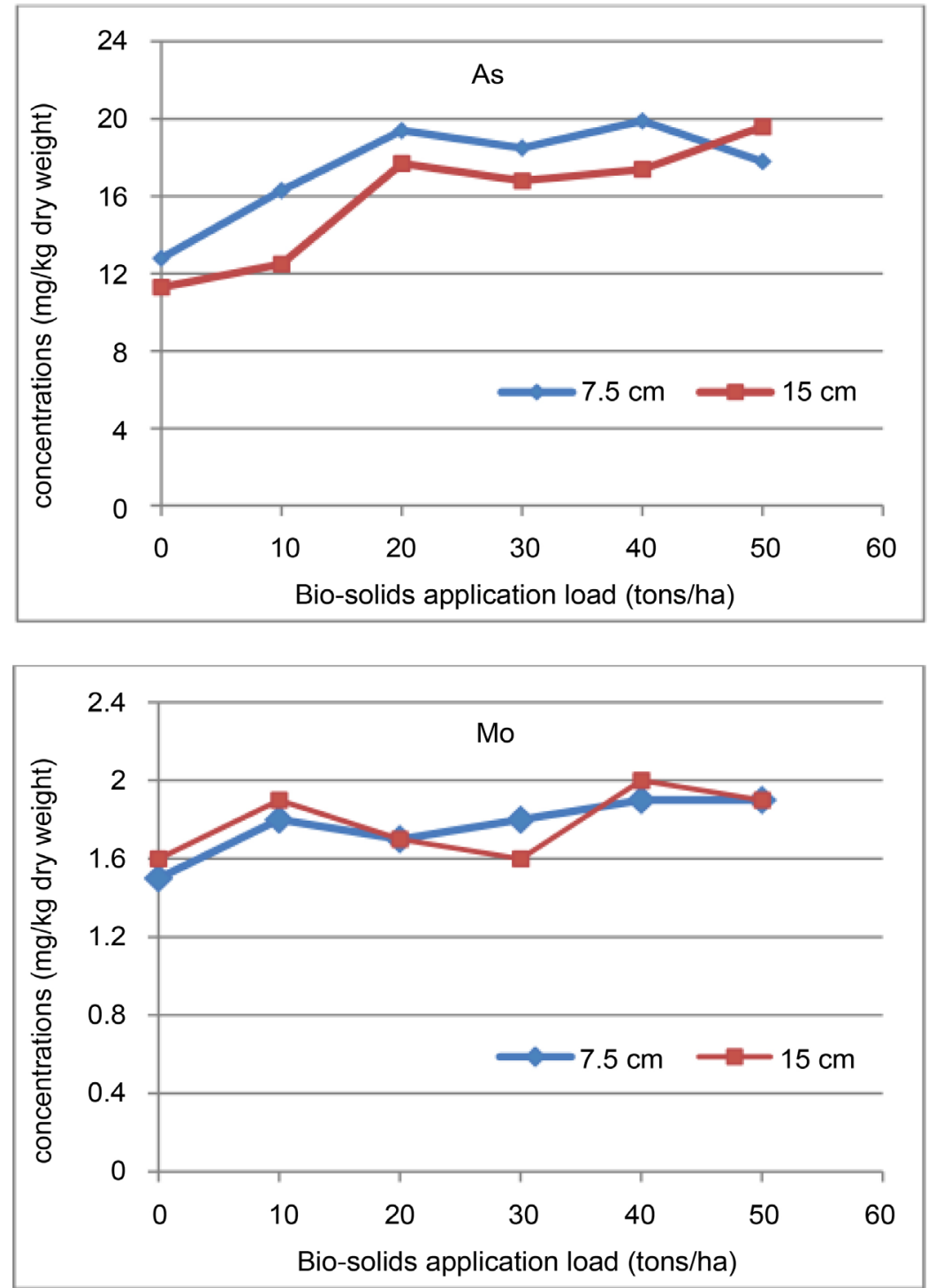

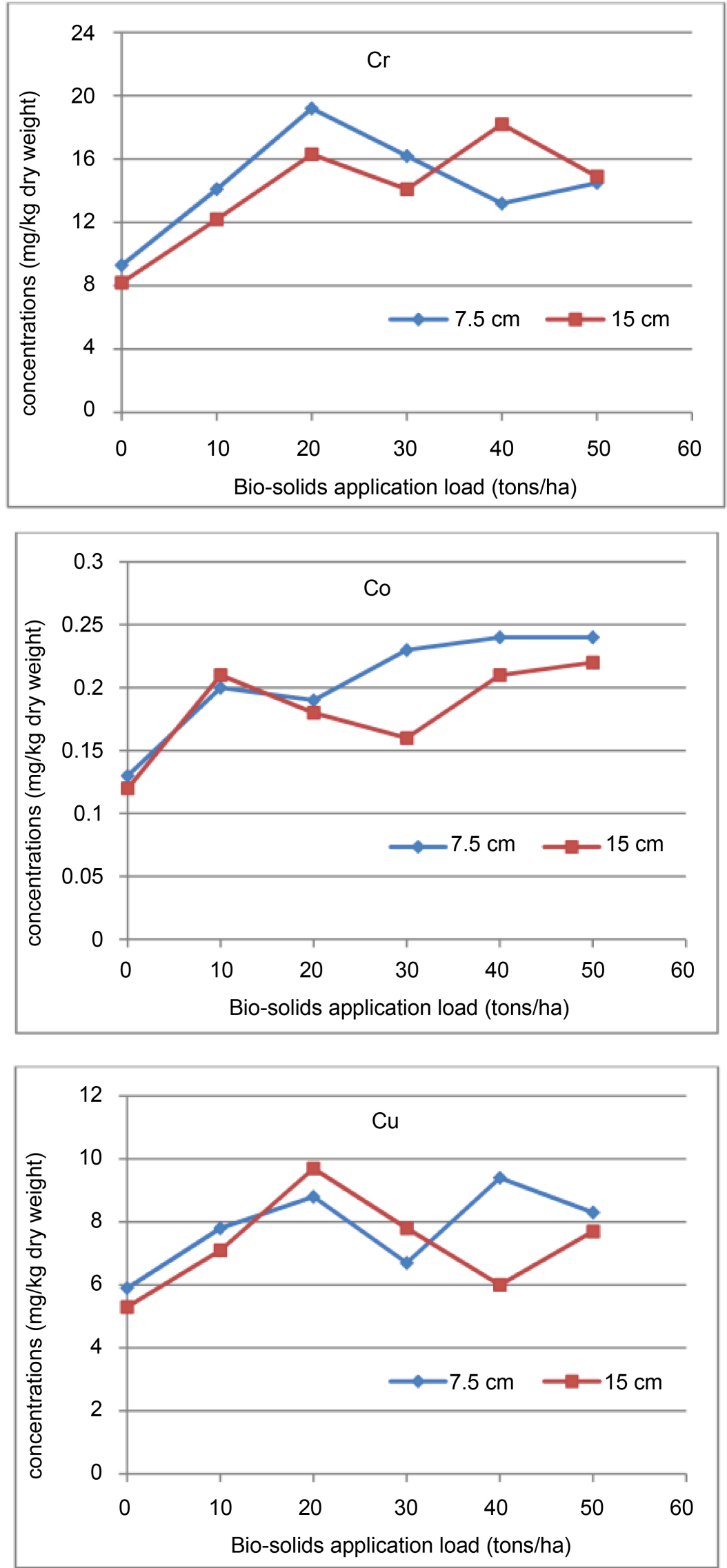

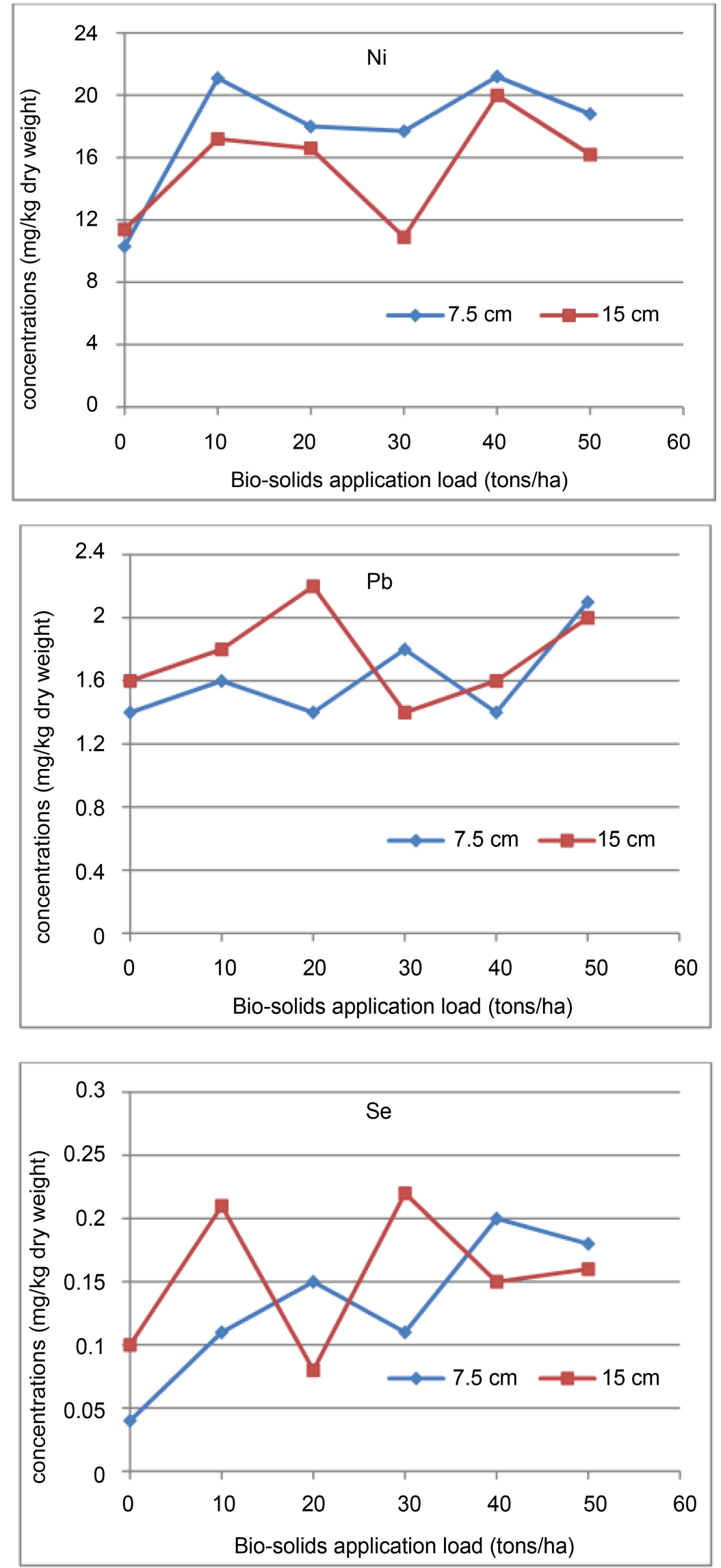


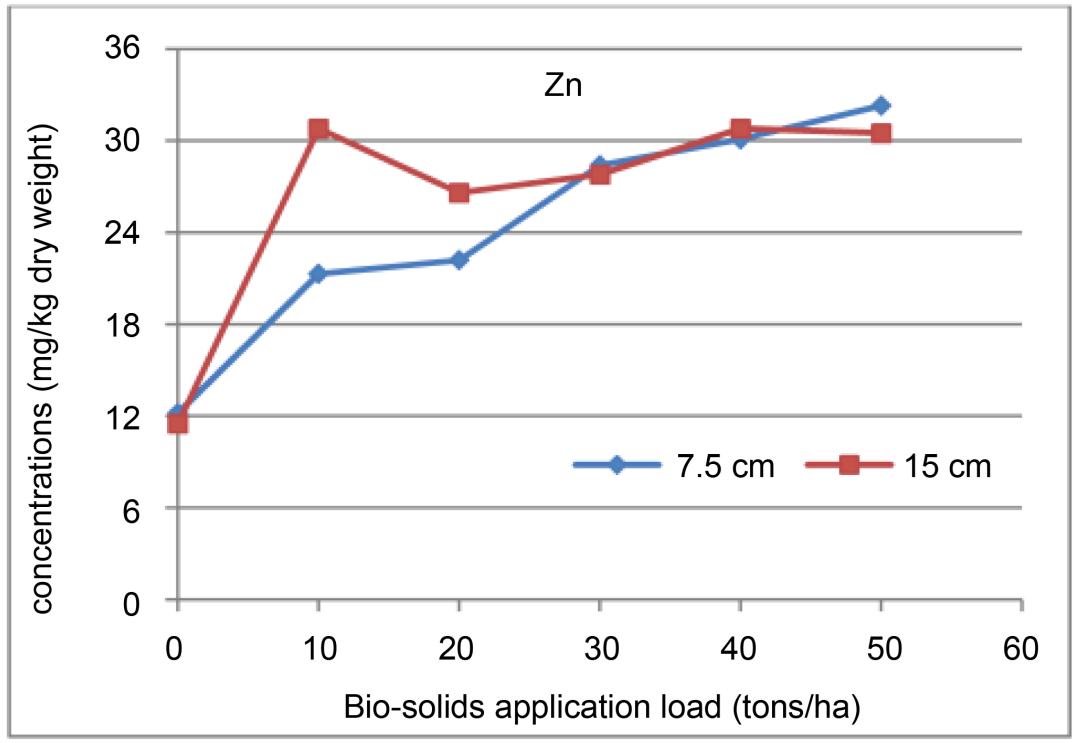

Figure 3. Heavy metals concentrations in soil.

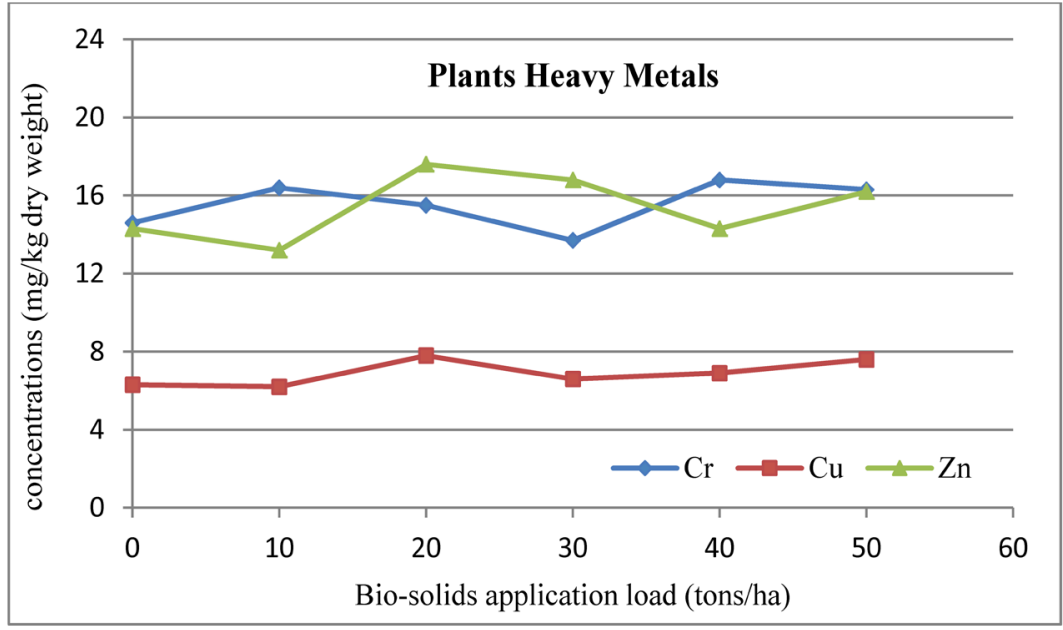

Figure 4. Heavy metals (Cr, $\mathrm{Cu}$ and $\mathrm{Zn}$ ) in plant tissue.

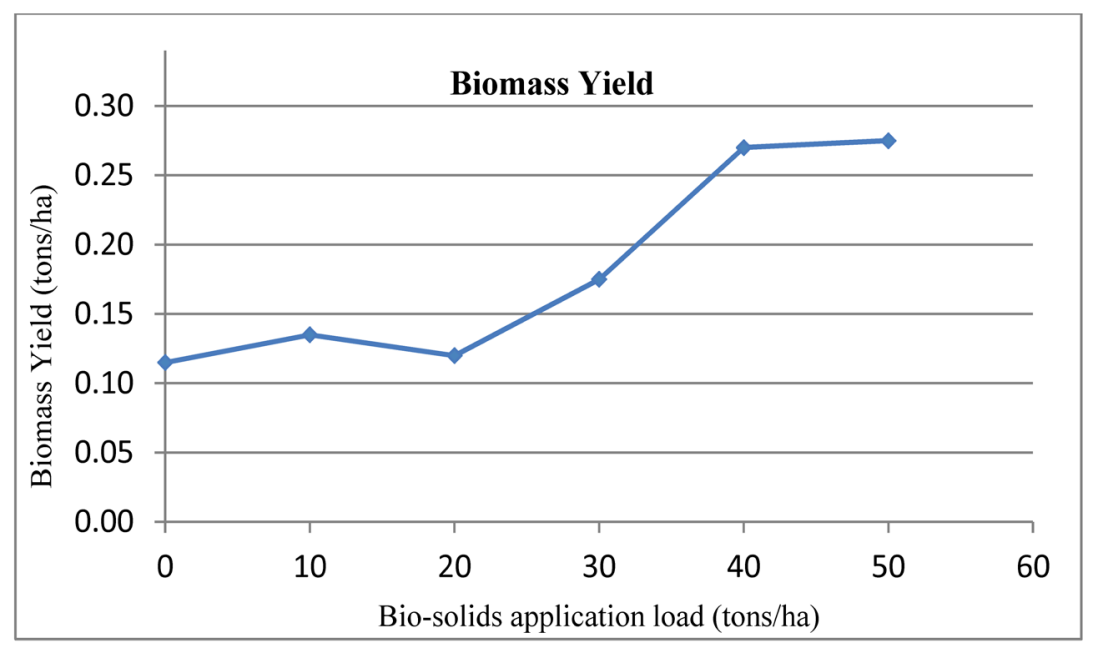

Figure 5. Biomass yield. 


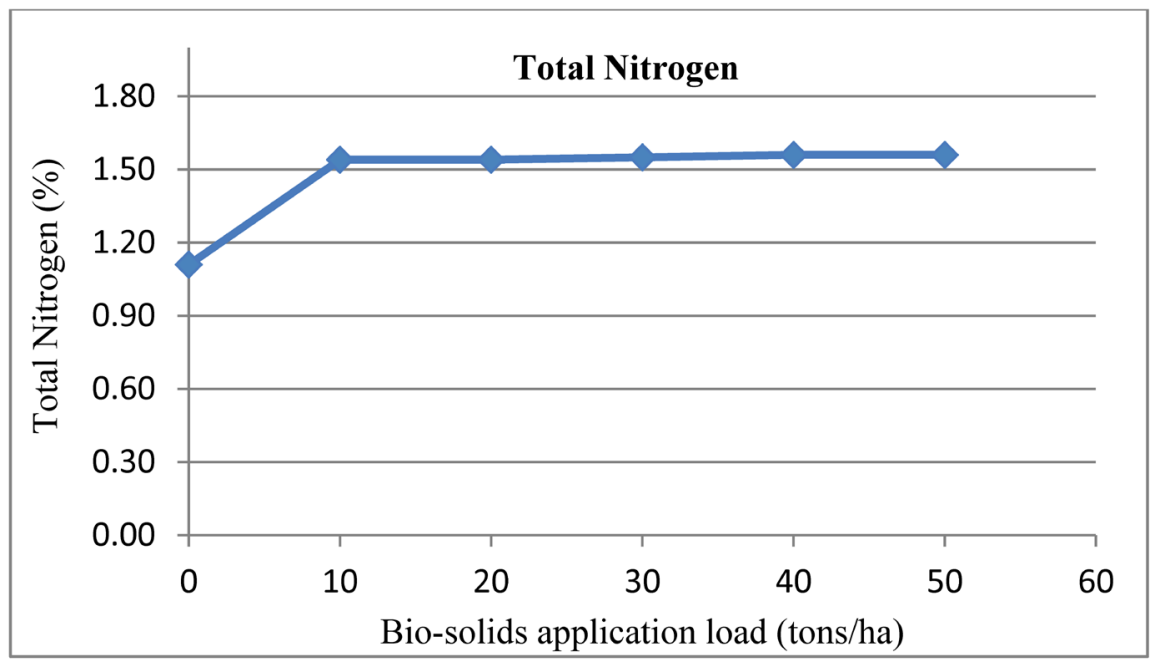

Figure 6. Total Nitrogen in plant.

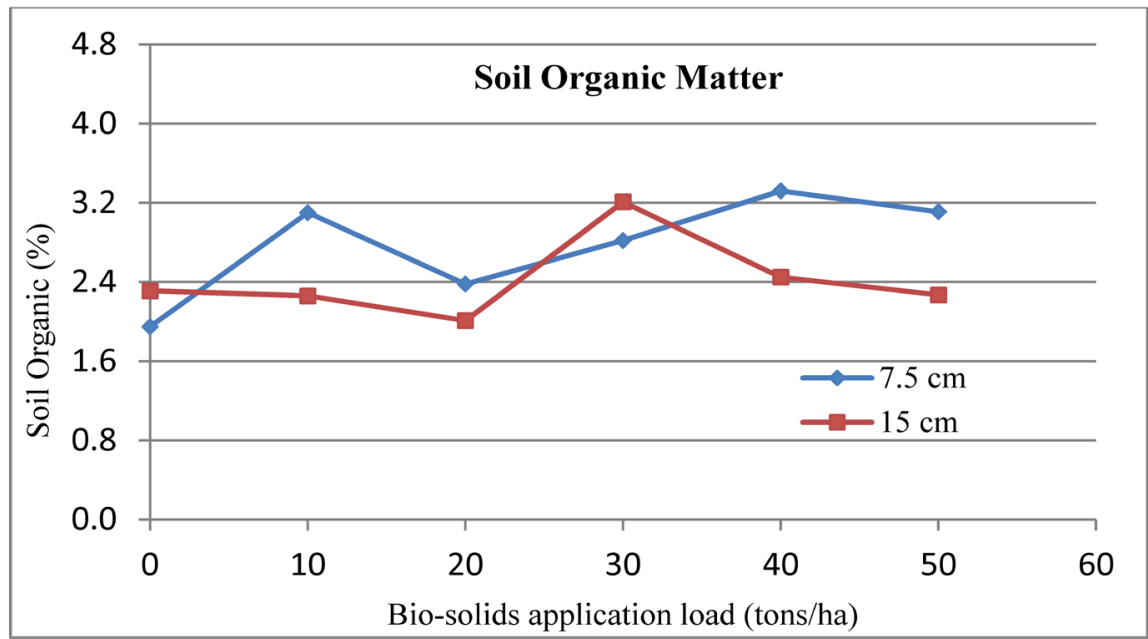

Figure 7. Soil organic matter (\%).

\subsection{Soil Physical Properties}

The effects of various bio-solids surface application rate on soil physical properties such as porosity, bulk density and moisture content at two different depths, 7.5 and $15 \mathrm{~cm}$ showed that there were no significant changes in these properties.

\section{Conclusions}

In general, trace elements can form insoluble precipitate with multivalent cation such as $\mathrm{Ca}$, the soil in the experiment site is calcareous soil containing $34.6 \%$ $\mathrm{CaCO}_{3}$. The precipitated trace elements formed may control the availability and mobility of trace element in soil solution. This was shown in the results where the heavy metals in the bio-solid were relatively high and increased their concentration in the soil, but for the plant tissues, they were nondetectable or had much smaller concentration than bio-solid and soil.

In the other hand, the productivity of soil measured by the biomass was significantly increased using bio-solid. The areas treated by 40 tons/ha or more 
yielded biomass more than 2.4 times the control plots.

The organic matters in soil were increases in the areas treated with bio-solid. The top soil $(7.5 \mathrm{~cm})$ samples showed increase in organic matter by $20 \%$ to $70 \%$ for the different application rates. The total Nitrogen in all plots treated with bio-solid increased by about $40 \%$. The physical properties of soil such as bulk density and porosity were not altered by the application of bio-solid.

The application of bio-solid results showed that it enhanced the nutrient content of soil in the form of organic matters and Nitrogen and increased the biomass production by more than 2.4 times. These results fall in line with the need for enhancing the fertility of degraded arid land soils to be able to support vegetation under limited amounts of rainfall and rehabilitating the natural vegetation cover. Also the application will control soil erosion, loss of organic matter, removal of nutrients, acidity, and destruction of soil structure.

\section{Acknowledgements}

The authors would like to acknowledge the financial support to conduct this applied research by the United States Agency for International Development (USAID). The authors also would like to thank The Hashemite University for their assistant and making the site available to conduct this study.

\section{References}

[1] AlAyyash, S., Al-Adamat, R., Al-Amoush, H., Al-Meshan, O., Rawjefih, Z., Shdeifat, A., Al-Harahsheh, A. and Al-Farajat, M. (2012) Runoff Estimation for Suggested Water Harvesting Sites in the Northern Jordanian Badia. Journal of Water Resource and Protection, 4, 127-132. https://doi.org/10.4236/jwarp.2012.43015

[2] Al-Adamat, R., AlAyyash, S., Al-Amoush, H., Al-Meshan, O., Rawajfih, Z., Shdeifat, A., Al-Harahsheh, A. and Al-Farajat, M. (2012) The Combination of Indigenous Knowledge and Geo-Informatics for Water Harvesting Sitting in the Jordanian Badia. Journal of Geographic Information System, 4, 366-376.

https://doi.org/10.4236/jgis.2012.44042

[3] Wang, H., Brown, S.L., Magesan, G.N., Slade, A.H., Clinton, P.W. and Payn, T.W. (2008) Technological Options for the Management of Bio-Solids. Environmental Science and Pollution Research, 15, 308-317. https://doi.org/10.1007/s11356-008-0012-5

[4] Torri, S.I., Corrêa, R.S. and Renella, G. (2014) Soil Carbon Sequestration Resulting from Biosolids Application. Applied and Environmental Soil Science, 2014, Article ID: 821768 .

[5] Giusquiani, P.L., Pagliai, M., Gigliotti, G., Businelli, D. and Benetti, A. (1995) Urban Waste Compost: Effects on Physical, Chemical, and Biochemical Soil Properties. Journal of Environmental Quality, 24, 175-182. https://doi.org/10.2134/jeq1995.00472425002400010024x

[6] Aguilar, R., Loftin, S.R. and Fresquez, P.R. (1994) Rangeland Restoration with Treated Municipal Sewage Sludge. In: Clapp, C.E., et al., Eds., Sewage Sludge: Land Utilization and the Environment, SSSA, Madison, WI, 211-220.

[7] Garcia, C., Hernández, T. and Costa, F. (1992) Variation in Some Chemical Parameters and Organic Matter in Soils Regenerated by the Addition of Municipal Solid Waste. Environment Management, 16, 763-768. 
https://doi.org/10.1007/BF02645666

[8] Pepper, I.L., Brooks, J.P. and Gerba, Ch.P. (2006) Pathogens in Biosolids. Advances in Agronomy, 90, 1-41.

[9] Sullivan, T.S., Stromberger, M.E., Pashchke, M.W. and Ippolito, J.A. (2006) LongTerm Impacts of Infrequent Biosolids Application on Chemical and Microbial Properties of a Semi-Arid Rangeland Soil. Biology and Fertility of Soils, 42, 258-266. https://doi.org/10.1007/s00374-005-0023-Z

[10] Jin, V.L., Johnson, M.V., Haney, R.L. and Arnold, J.G. (2011) Potential Carbon and Nitrogen Mineralization in Soils from a Perennial Forage Production System Amended with Class B Biosolids. Agriculture, Ecosystems \& Environment, 141, 461-465.

[11] Lima, V., et al. (2016) The Cumulative Effects of Sewage Sludge Compost on Raphanus sativus L: Growth and Soil Properties. Green and Sustainable Chemistry, 6, 1-10. https://doi.org/10.4236/gsc.2016.61001

[12] Ozyazici, M.A. (2013) Effects of Sewage Sludge on the Yield of Plants in the Rotation System of Wheat-White Head Cabbage-Tomato. Eurasia Journal of Soil Science, 2, 35-44.

[13] Harris-Pierce, R.L., Redente, E.F. and Barbarick, K.A. (1995) Sewage Sludge Application Effects on Runoff Water Quality in a Semiarid Grassland. Journal of Environmental Quality, 24, 112-115. https://doi.org/10.2134/jeq1995.00472425002400010016x

[14] González, M., Mingorance, M.D., Sánchez, L. and Aránzazu, P. (2008) Pesticide Adsorption on a Calcareous Soil Modified with Sewage Sludge and Quaternary Alkyl-Ammonium Cationic Surfactants. Environmental Science and Pollution Research, 15, 8-14. https://doi.org/10.1065/espr2007.02.387

[15] McCurry, G.N. (1995) Evaluating Infiltration-Related Water Quality Impacts Associated with Land Application of Biosolids in Arid and Semi-Arid Settings. Proceedings of Effects of Land Application of Biosolids in Arid and Semi-Arid Environment conference, Fort Collins, 16-19 May 1995 (Sponsored by USEPA).

[16] Moffet, C.A., Zartman, R.E., Wester, D.B. and Sosebee R.E. (2005) Surface Biosolids Application. Journal of Environmental Quality, 34, 299-311. https://doi.org/10.2134/jeq2005.0299

[17] Scharenbroch, B.C., Meza, E.N., Catania, M. and Fite, K. (2013) Biochar and Biosolids Increase Tree Growth and Improve Soil Quality for Urban Landscapes. Journal of Environmental Quality, 42, 1372-1385. https://doi.org/10.2134/jeq2013.04.0124

[18] Martinez, F., Cuevas, G., Calvo, R. and Walter, I. (2003) Biowaste Effects on Soil and Native Plants in Semiarid Ecosystem. Journal of Environmental Quality, 32, 472-479. https://doi.org/10.2134/jeq2003.4720

[19] Fresquez, P., Francis, R. and Dennis, G. (1990) Effects of Sewage Sludge on Soil and Plant Quality in a Semiarid Grassland Community. Journal of Environmental Quality, 19, 324-329. https://doi.org/10.2134/jeq1990.00472425001900020020x

[20] Usman, K., Khan, S., Ghulam, S., Khan, M., Khan, N., Khan, M. and Khalil, S. (2012) Sewage Sludge: An Important Biological Resource for Sustainable Agriculture and Its Environmental Implications. American Journal of Plant Sciences, 3, 1708-1721. https://doi.org/10.4236/ajps.2012.312209

[21] Harmel, R.D., Zartman, E.R., Mouron, C., Wester, B.D. and Sosebee, E.R. (1997) Modeling Ammonia Volatilization from Biosolids Applied to Semiarid Rangeland. Soil Science Society of America Journal, 61, 1794-1798. https://doi.org/10.2136/sssaj1997.03615995006100060035x

[22] Whitrord, W.G., Aldon, E.F., Freckman, D.W., Steinberger, Y. and Parker, L.W. 
(1989) Effects of Organic Amendments on Soil Biota on a Degraded Rangeland. Journal of Range Management, 42, 56-60. https://doi.org/10.2307/3899659

[23] Proust, D., Mathé, V. and Lévêque, F. (2013) Distribution and Mobility of Zn, Pb and Cd in a Sewage Sludge-Amended Soil. Open Journal of Soil Science, 3, 347-355. https://doi.org/10.4236/ojss.2013.38040

[24] Lu, Q., He, Z.L. and Stoffella, P.J. (2012) Land Application of Biosolids in the USA: A Review. Applied and Environmental Soil Science, 2012, Article ID: 201462.

[25] Oudeh, M., Khan, M. and Scullion, J. (2002) Plant Accumulation of Potentially Toxic Elements in Sewage Sludge as Affected by Soil Organic Matter Level and Mycorrhizal Fungi. Environmental Pollution, 116, 293-300.

Submit or recommend next manuscript to SCIRP and we will provide best service for you:

Accepting pre-submission inquiries through Email, Facebook, LinkedIn, Twitter, etc. A wide selection of journals (inclusive of 9 subjects, more than 200 journals) Providing 24-hour high-quality service User-friendly online submission system Fair and swift peer-review system Efficient typesetting and proofreading procedure Display of the result of downloads and visits, as well as the number of cited articles Maximum dissemination of your research work

Submit your manuscript at: http://papersubmission.scirp.org/

Or contact jep@scirp.org 